\title{
Financing Education under Samagra Shiksha Abhiyan: An Initial Analysis in Selected States of India
}

\author{
Pallavi Khanna \\ Ph.D. Research Scholar, Department of Economics, Jamia Millia Islamia, Jamia Nagar, Okhla, \\ New Delhi - 110025, India; pallavikhanna20@gmail.com
}

Received: 12 March 2021

Accepted: 14 oct 2021

Published: 15 Nov 2021

\begin{abstract}
Funding policies in the education sector have undergone significant change over the years in India. In recent years, one such big change is the integration of three major flagship programmes for education, namely: Sarva Shiksha Abhiyan (SSA), Rashtriya Madhyamik Shiksha Abhiyan (RMSA) \& Teacher Education (TE) under one umbrella scheme known as Samagra Shiksha Abhiyan (SMSA). As financial year 2018-19 is the initial year for implementation of the scheme, hence, this paper explores the planning and budgeting aspects of the Samagra Shiksha Abhiyan in selected states of India. The study has been carried out for the eight states, viz., Andhra Pradesh, Bihar, West Bengal, Uttarakhand, Uttar Pradesh, Himachal Pradesh, and Delhi, for the period of 2018-19 to 2019-20. The paper studies the financing of education under SMSA. The paper also analyses the distribution of support from the union government under the scheme. Drawing on the lessons from such analysis, the historical background and past experiences of implementation of previous education schemes, viz., Sarva Shiksha Abhiyan, Rashtriya Madhyamik Shiksha Abhiyan, and Teacher Education, the paper examines the design and ground level challenges of the Samagra Shiksha Abhiyan in selected states of India.
\end{abstract}

Keywords: Budget, Elementary Education, Samagra Shiksha Abhiyan, Secondary Education, Teacher Education, Union Government

JEL classification: A20, I28, I20

\section{Introduction}

Education as a subject was shifted from the state list to the concurrent list in 1976, under article 42 of the constitution, which enables the joint responsibility of the federal and state governments in its planning, management and provisioning. In order to universalise access, promote equity and improve the quality of education at all levels, both the union and state governments, time to time, have implemented various Central Sponsored Schemes (CSS). These schemes are operationalised by the Ministry of Education, and executed jointly in collaboration with state education departments. Among all the schemes, in the financial year 2000-01, the Government of India (GoI) implemented the Sarva Shiksha Abhiyan, ${ }^{-6}$ one of the largest and key flagship programme with an aim to universalise elementary education in the country. Its objective of universalising elementary education was further strengthened by the enactment of the Right of
Children to Free and Compulsory Education (RTE) Act, 2009 which gave a legal mandate to provide free and compulsory education to all the children in the 6-14 years age bracket. Sarva Shiksha Abhiyan was later followed by the implementation of the Rashtriya Madhyamik Shiksha Abhiyan in the FY 2009-10, targeted at enhancing access to secondary education and improving its quality by achieving the gross enrolment ratio exceeding 90 per cent by 2017 and universal retention by 2020. -9 Also, another important nationwide Central Sponsored Scheme (CSS) was launched in 1987, on teacher education, $\underline{6}$ to provide infrastructural and institutional support to Government Teacher Education Institutions (TEIs).

As per the latest data available from the Ministry of Education (Erstwhile Ministry of Human Resource Development) ${ }^{5,13}$ India has made significant strides towards elementary education i.e., in the financial year 2000-01, the gross enrolment ratio at the elementary level was around 81.6 per cent which increased to 96.1 
per cent in 2018-19. However, recent data from the National sample survey (NSS) $75^{\text {th }}$ round (2017), $\frac{8}{\text { which }}$ was conducted between July 2017 and June 2018, shows that almost $22 \%$ of children between the 15 and 18 years age group never enrolled in secondary education and $20 \%$ of enrolled children dropped out for various reasons. This figure shows that there has been very slow progress towards secondary education in India. Thus, India poses a major challenge towards achieving Sustainable Development Goal 4 of education by $2030 . \underline{12}$

The financial year 2018-19 marked a major change in the schematic structure of school education where the Ministry of Education (Erstwhile Ministry of Human Resource Development) amalgamated three major flagship programmes for education in India, namely: Sarva Shiksha Abhiyan (SSA), Rashtriya Madhyamik Shiksha Abhiyan (RMSA) \& Teacher Education under one umbrella scheme known as Samagra Shiksha Abhiyan..$^{10}$ Since its proclamation, there have been a lot of discussions regarding its budgeting, implementation, monitoring etc. Given this backdrop, this paper analyses and explores the quantitative aspects of financing of Samagra Shiksha Abhiyan in selected states of India, along with a brief overview of the policy.

The present study at hand is different from previously conducted studies as it attempts to unpack the structure of financial planning and devolution of funds associated with the Samagra Shiksha Abhiyan, a new integrated scheme for School Education. In doing so, the study attempted to look at how states are designing their resources under Samagra Shiksha Abhiyan to promote equitable and inclusive quality education. As FY 201819 is the first year of proclamation of Samagra Shiksha Abhiyan, this preliminary study has focussed on specifically five important financial indicators, viz., proposed budget by individual states, approved outlays by the Project Approval Board (PAB), funds released by the union government, total funds available and total funds utilised for Samagra Shiksha Abhiyan. Further, the study attempted to explore the distribution of approved budget for different interventions to reflect the priorities of the states. There are a large number of interventions like Gender \& equity, Inclusive education, Access and retention, RTE entitlement and quality improvements etc. that are very responsive in character/nature. The most important highlight of the study is to provide a baseline to generate insights needed to suggest corrective measures at different levels for fostering equitable and quality education.
The present paper is divided into four sections. Section 1 highlights the introduction aspect of the study wherein background and brief review of the topic is discussed. Section 2 describes the broad objectives and method of data analysis. Section 3 examines the financial outlay of the scheme across eight Indian states, along with the brief overview of the policy. Section 4 provides the details of component-wise distribution of resources for the scheme. Section 5 deals with the contribution of the union government in funding Samagra Shiksha Abhiyan. Section 6 examines the pattern of allocation and utilisation of resources under the scheme. The last section presents the conclusion of the study.

\section{Objectives and Research Methodology}

The objectives pertaining to the study and the research methodology used in the paper has been explained in this section.

\subsection{Objectives of the Study}

The present study assumes the following objectives:

i. The objective of the study is to examine the proposed and approved budget outlays reported for Samagra Shiksha Abhiyan in Andhra Pradesh, Bihar, Delhi, Himachal Pradesh, Maharashtra, Uttar Pradesh, Uttarakhand and West Bengal.

ii. To analyse the component-wise approved budget for the scheme across eight states for the two financial years, viz., 2018-19 and 2019-20.

iii. The study also aims to analyse the distribution of resources by the central government under Samagra Shikha Abhiyan in the selected states.

iv. Another important objective is to analyse the financial pattern of allocation and expenditure under Samagra Shiksha Abhiyan in selected states of India, which is crucial for understanding of the financial performance of the scheme during the study period.

\subsection{Research Methodology and Data}

\section{Consideration}

In order to examine the above mentioned objectives, the present study used the exploratory research design wherein, the purposive sampling technique was adopted for undertaking the study. The Project Approval Minutes (PAB) 
of Samagra Shiksha abhiyan are the primary source of data for the present study, along with the other publicly available government data sources such as the Union Budget (Various years), the website of the Samagra Shiksha Abhiyan, reports of Ministry of Education (MoE). The time period of the study covers two years from financial year (FY) 2018-19 to FY 2019-20. This period is selected for the study because prior to FY 2018-19, funds for Central Sponsored Schemes i.e., Sarva Shiksha Abhiyan, Rashtriya Madhyamik Shiksha Abhiyan \& Teacher Education were routed through autonomous implementing bodies known as State Implementation Socities (SISs), which may have led to a duplication of efforts. Since the launch of the integrated scheme in FY 2018-19, the funds are routed through a single implementation society, allowing us to capture a broader picture of education finance across states of India. The study has chosen eight Indian states - Andhra Pradesh, West Bengal, Bihar, Uttarakhand, Uttar Pradesh, Himachal Pradesh and Delhi - a depiction of both better and poor performing states in education across different geographical zones (See Appendix Table A1). ${ }^{1}$ Data has been analysed with the help of tables, percentages, ratios to arrive at the results.

\section{Samagra Shiksha Abhiyan: An Overview}

Samagra Shiksha Abhiyan (SMSA) - An integrated scheme for the school education sector extending from preschool to senior secondary was launched in April 2018 by the Government of India with an aim to ensure inclusive and equitable quality education for all. The main outcomes of the schemes are envisaged as universal access, quality and equity, promoting Vocational Education and strengthening of Teacher Education Institutions. ${ }^{10}$ Towards this direction, the initiative aims to focus on 11 key components of education,,$\frac{3,6}{v i z}$., Access \& Retention, Quality Interventions, Vocational Education, Teacher Education, Inclusive Education, Gender \& Equity, Monitoring of the Scheme, Programme Management, RTE Entitlements, Sports \& Physical Education and Salary of Teachers (Samagra Shiksha Ministry of Education, Government of India).

Samagra Shiksha Abhiyan has the following salient features $, 1,10,2$ :

i. To treat education holistically as a continuum from pre-school, primary, upper primary, secondary to Senior Secondary levels. ii. In Financial Year 2018-19, Samagra Shiksha Abhiyan was classified as the key initiative for achieving the national development agenda and was brought under the purview of the National Education Mission (NEM).

iii. The funding of SMSA is shared between the centre and states, (Except for eight North Eastern states and 3 Himalayan states) in the ratio of 60:40 respectively. In the case of North Eastern states and Himalayan states, funding is shared in the ratio of 90:10. In the case of Union Territories, the entire funds of Samagra Shiksha Abhiyan are provided by the centre.

iv. The ministry does the annual allocation for the states and union territories on the basis of performance (For instance, National Achievement Survey (NAS) results, enrolment of students, Gender Parity Index and various other performance indicators).

v. Unlike Sarva Shiksha Abhiyan and Rashtriya Madhyamik Shiksha Abhiyan (both had autonomous implementation bodies), there would be a single implementation society for the integrated scheme at the state level.

vi. The process of execution of Samagra Shiksha Abhiyan requires that: (i) Annual Work Plan and Budgets (AWP\&B) are created, (ii) Approvals are obtained from the Ministry of Education (MoE), (iii) installments are released to state SMSA implemention society, and (iv) expenditures are incurred.

vii. The release of funds under Samagra Shiksha Abhiyan will be guided by the following conditions: (i) The first installment of funds is released to the State implementation society only after the Annual Work Plan \& Budget is approved by the Ministry of Education, (ii) The state government also released its share to State implementation society within one month of the release of the central share, (iii) The release of the second installment from the centre is contingent upon the request letter from the state for release, latest expenditure statement of the state implementation society, fund utilisation certificate and Audit report of the Samagra Shiksha Abhiyan for the previous year.

viii. The release of funds for Elementary, Secondary \& Teacher Education would be through a single budget head. However, for the purpose of analysing the funds transferred to each component, the sub-heads have been classified separately. 
ix. Regular monitoring and review of the progress of the programme is done with the help of the State Project Office (SPO), District Project office (DPO)/District Education Officer (DEO) and Block Education Officer.

\subsection{Proposed vs. Approved Budget}

For the present study, so as to understand the budgeting process of the scheme in selected states of India, two financial indicators, viz., proposed budget and approved budget, have been analysed first. The term 'Approved Budget' available in the Project Approval Board (PAB) minutes shows the amount of money approved by the Project Approval Board to run a programme based on the Annual Work Plan \& Budget (AWP\&B) submitted by the states, whereas 'Proposed Budget' are approved by the Project Approval Board for Samagra Shiksha Abhiyan after negotiations with states.

Table 1 depicts the proposed vs. approved outlay for Samgara Shiksha Abhiyan across 8 states (Andhra Pradesh, Bihar, Delhi, Himachal Pradesh, Maharashtra, Uttar Pradesh, Uttarakhand and West Bengal) for the period of two years, i.e., 2018-19 and 2019-20. It clearly reveals that the funds approved for Samagra Shiksha Abhiyan inclined constantly for all states except for Uttarakhand, but witnessed a significant gap between the approved and proposed budget both in FY 2018-19 and FY 2019-20.

Taking a closer inspection at the figures by the states separately, it is evident that no state has been approved for 100 per cent of the proposed budget under the SMSA. There are significant differences between the budget proposed by the individual states and budget approved by the Ministry of Education. The Project Approval Board meetings for Samagra Shiksha Abhiyan were held between May-June (See Appendix Table A2) where states presented its Annual Work Plan and Budget ${ }^{6}$ of Rs. 250055 lakh, Rs. 1381422 lakh, Rs. 91363 lakh, Rs. 90206 lakh, Rs. 432216 lakh, Rs. 997382 lakh, Rs. 95386 lakh and Rs. 500804 lakh for Andhra Pradesh, Bihar, Delhi, Himachal Pradesh, Maharashtra, Uttar Pradesh, Uttarakhand, and West Bengal in FY 2018-19. Against this proposal, the Project Approval Board approved Rs. 192717 lakh, Rs. 719280 lakh, Rs. 39371 lakh, Rs. 64473 lakh, Rs. 193122 lakh, Rs. 913201 lakh, Rs. 83086 lakh and Rs. 367382 lakh in these eight states respectively. This implies a shortfall of twenty three per cent, fourty eight per cent, fifty seven per cent, twenty nine per cent, fifty five per cent, eight per cent, thirteen per cent and twenty seven per cent funds from the proposed outlay in FY 2018-19. Again, in FY 2019-20, the total approved budget for Samagra Shiksha Abhiyan in Andhra Pradesh, Bihar, Delhi, Himachal Pradesh, Maharashtra, Uttar Pradesh, Uttarakhand, and West Bengal witnessed a deviation of thirty six per cent, fifty five per cent, eighty two per cent, twenty five per cent, twenty eight per cent, fifteen per cent, thirty two per cent and forty eight per cent respectively. Thus, the funds approved as a proportion of those proposed for Samagra Shiksha Abhiyan were low across all the eight states since the scheme has been implemented.

\section{Component-wise Distribution of Resources under SMSA}

The total approval does not reveal the share of each component under Samagra Shiksha Abhiyan, which assumes more importance than the total approval. Therefore, it is pertinent to examine priorities being given to the components of total approval under Samagra Shiksha Abhiyan. Figure 1 and 2 shows the comparison of funds approved under three broader components of school education ${ }^{6}:$ Elementary Education, Secondary Education and Teacher Education in FY 2018-19 and 2019-20 in selected states of India. It is evident from the data that the largest proportion of funds in the programme is set aside for elementary education across all 8 states. The Second highest share of approval is under the component Secondary education, leaving very little room for Teacher Education. This pattern clearly shows that teacher education is the most neglected area of intervention in selected states of India. Thus, the analysis evidences that the integration of SSA, RMSA and TE under one umbrella scheme has not helped much in improving the scenario of secondary and teacher education in selected states of India.

As discussed above, the share of approved outlay for several components under SMSA only reflects the priority of the government, but it does not tell us which component within Elementary, Secondary and Teacher Education is getting priority. To understand this, the present study intends to look at approved outlay for all interventions reported in the Project Approval Board Minutes. ${ }^{-}$These are (1) Access \& Retention; (2) Quality Interventions; (3) Vocational Education; (4) Teacher Education; (5) Inclusive Education; (6) Gender \& Equity; (7) Monitoring of the Scheme; (8) Programme Management; (9) RTE 
Table 1. Proposed vs. Approved Outlay for SMSA in Selected States in India (Rs. in lakhs)

\begin{tabular}{|l|c|c|c|c|c|c|}
\hline \multicolumn{1}{|c|}{ States } & Proposed & Approved & $\begin{array}{c}\text { Shortage/ } \\
\text { Excess }\end{array}$ & Proposed & $\begin{array}{c}\text { Approved } \\
\text { 2018-19 }\end{array}$ & $\begin{array}{c}\text { Shortage/ } \\
\text { Excess }\end{array}$ \\
\hline Andhra Pradesh & 250055 & 192717 & 57338 & 399842 & 254874 & 144968 \\
\hline Bihar & 1381422 & 719280 & 662142 & 1633320 & 732627 & 900693 \\
\hline Delhi & 91363 & 39371 & 51992 & 333854 & 59032 & 274822 \\
\hline $\begin{array}{l}\text { Himachal } \\
\text { Pradesh }\end{array}$ & 90206 & 64473 & 25734 & 91618 & 68877 & 22741 \\
\hline Maharashtra & 432216 & 193122 & 239094 & 353196 & 253139 & 100057 \\
\hline Uttar Pradesh & 997382 & 913201 & 84182 & 1082074 & 922908 & 159166 \\
\hline Uttarakhand & 95386 & 83086 & 12300 & 110896 & 75281 & 35615 \\
\hline West Bengal & 500804 & 367382 & 133422 & 816780 & 424849 & 391931 \\
\hline
\end{tabular}

Note: ${ }^{\star}$ It excludes the spill over of the previous financial year.

Source: PAB Minutes $(2018,2019)$

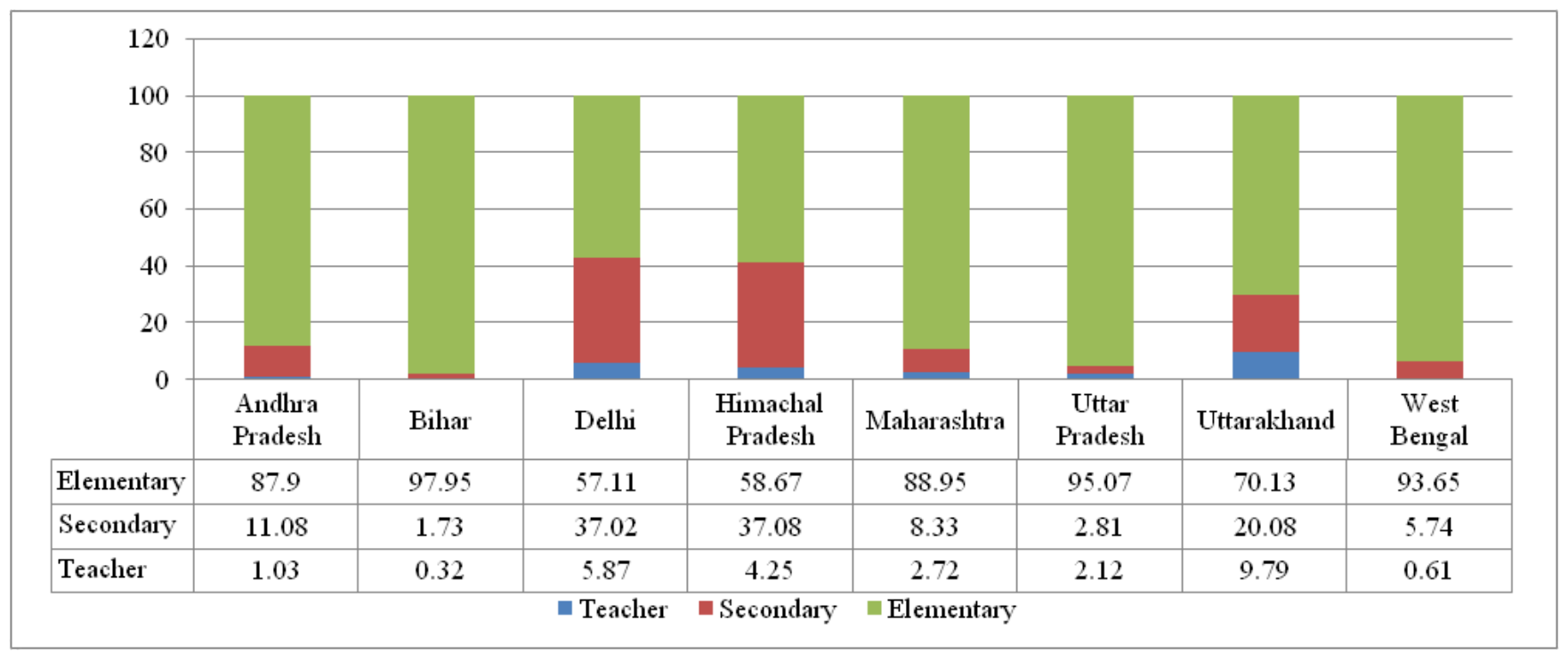

Source: PAB Minutes, 2018 and Author's own calculations.

Figure 1. Component-wise Percentage of Total Approval for Samagra Shiksha Abhiyan, 2018-19.

Entitlements; (10) Sports \& Physical Education and (11) Salary of Teachers (See Appendix Table A3).

An assessment of funds approved among the different components of Samagra Shiksha Abhiyan in selected states of India shows that the total amount approved was Rs. 2691023.51 lakh during Biennium Average (201820). .6 Out of this amount, the various components received in the following manner: (1) Access \& Retention (Rs. 71332.06 lakh); (2) Quality Interventions (Rs. 483566.08 lakh); (3) Vocational Education (Rs. 34946.11 lakh); (4) Teacher Education (Rs. 45127.50 lakh); (5) Inclusive
Education (Rs. 46756.24 lakh); (6) Gender \& Equity (Rs. 189377.53 lakh); (7)Monitoring of the Scheme (Rs. 2472.55 lakh); (8) Programme Management (Rs. 127719.47 lakh); (9) RTE Entitlements (Rs. 539895.37 lakh); (10) Sports \& Physical Education (Rs. 27010.09 lakh); and (11) Salary of Teachers (Rs. 1122820.52 lakh). Their respective proportionate shares were as follows: (1) Access \& Retention (2.65 per cent); (2) Quality Interventions (17.97 per cent); (3) Vocational Education (1.30 per cent); (4) Teacher Education (1.68 per cent); (5) Inclusive Education (1.74 per cent); (6) Gender \& Equity 


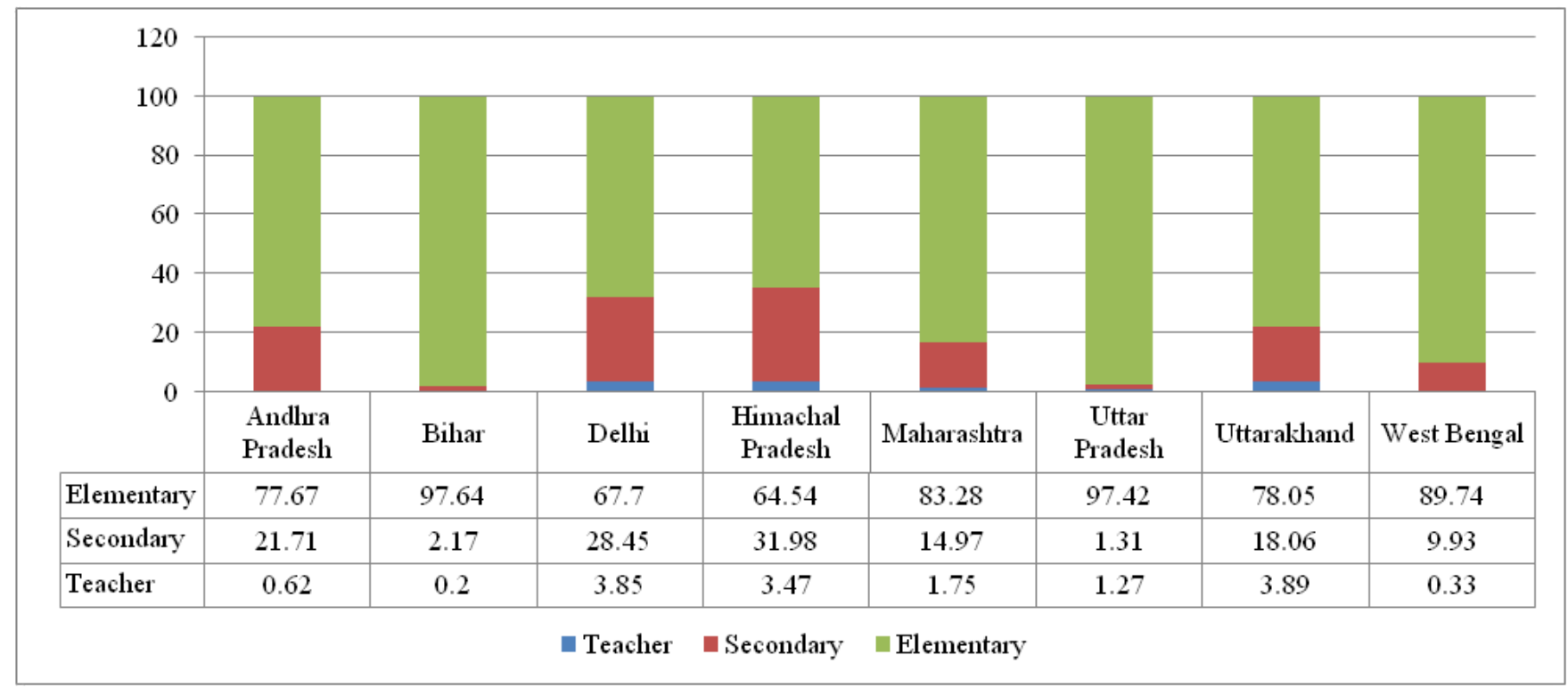

Source: PAB Minutes, 2019 and Author's own calculations.

Figure 2. Component-wise Percentage of Total Approval for Samagra Shiksha Abhiyan, 2019-20.

Table 2. Intervention-wise Approved Budget under SMSA in Selected States of India, 2018-19 to 2019-20 (Biennium Average) (Rs. in lakhs)

\begin{tabular}{|c|c|c|c|c|c|c|c|c|c|c|c|c|}
\hline States & $\begin{array}{l}\text { Access \& } \\
\text { Retention }\end{array}$ & $\begin{array}{c}\text { RTE } \\
\text { Entitlement }\end{array}$ & $\begin{array}{c}\text { Quality } \\
\text { Interventions }\end{array}$ & $\mathrm{TE}$ & $\begin{array}{l}\text { Teacher } \\
\text { Salary }\end{array}$ & $\begin{array}{c}\text { Gender \& } \\
\text { Equity }\end{array}$ & IE & VE & $\begin{array}{c}\text { Sports \& } \\
\text { Physical } \\
\text { Education }\end{array}$ & MIS & \begin{tabular}{c|} 
Programme \\
Management
\end{tabular} & Total \\
\hline $\begin{array}{l}\text { Andhra } \\
\text { Pradesh }\end{array}$ & 8320.52 & 35184.17 & 70231.62 & 10696.58 & 45800.46 & 41648.97 & 4658.60 & 4540.79 & 856.18 & 115.37 & 10656.94 & 232710.19 \\
\hline Bihar & 21933.07 & 171275.50 & 82916.18 & 1866.21 & 367653.90 & 33240.27 & 6812.83 & 142.50 & 5031.35 & 512.52 & 34569.22 & 725953.55 \\
\hline Delhi & 3117.99 & 13146.36 & 14237.83 & 2263.85 & 8728.80 & 642.10 & 3827.53 & 462.27 & 349.00 & 83.00 & 2342.94 & 49201.65 \\
\hline $\begin{array}{l}\text { Himachal } \\
\text { Pradesh }\end{array}$ & 1689.81 & 4556.51 & 27215.53 & 2566.53 & 13193.10 & 990.38 & 372.74 & 11467.76 & 1419.58 & 27.82 & 3174.98 & 66674.73 \\
\hline Maharashtra & 5542.64 & 85420.54 & 62817.06 & 4838.01 & 19756.50 & 4456.08 & 19148.97 & 7697.99 & 2375.98 & 451.21 & 10625.25 & 223130.21 \\
\hline $\begin{array}{l}\text { Uttar } \\
\text { Pradesh }\end{array}$ & 8894.22 & 149384.30 & 140699.90 & 15547.78 & 439282.10 & 101690.50 & 5978.55 & 1197.00 & 10755.95 & 906.99 & 43716.87 & 918054.16 \\
\hline Uttarakhand & 8336.42 & 11505.96 & 24525.12 & 5531.10 & 20822.26 & 1823.49 & 348.76 & 1014.94 & 1457.25 & 47.41 & 3770.64 & 79183.33 \\
\hline \multirow[t]{2}{*}{ West Bengal } & 13497.40 & 69422.03 & 60922.84 & 1817.46 & 207583.40 & 4885.76 & 5608.26 & 8422.86 & 4764.82 & 328.25 & 18862.64 & 396115.70 \\
\hline & 71332.06 & 539895.37 & 483566.08 & 45127.50 & 1122820.52 & 189377.53 & 46756.24 & 34946.11 & 27010.09 & 2472.55 & 127719.47 & 2691023.51 \\
\hline Per cent & 2.65 & 20.06 & 17.97 & 1.68 & 41.72 & 7.04 & 1.74 & 1.30 & 1.00 & 0.09 & 4.75 & 100.00 \\
\hline
\end{tabular}

Note: $\mathrm{TE}=$ Technical Education, $\mathrm{IE}=$ Inclusive Education, $\mathrm{VE}=$ Vocational Education and MIS = Monitoring of the Scheme.

Source: PAB Minutes $(2018,2019)$, SMSA reports and Author's own calculation. 
(7.04 per cent); (7) Monitoring of the Scheme (0.09 per cent); (8) Programme Management (4.75 per cent); (9) RTE Entitlements (20.06 per cent); (10) Sports \& Physical Education (1.00 per cent); and (11) Salary of Teachers (41.72 per cent). Thus, the maximum budget approved was made for Salary of Teachers ( 41.72 per cent), followed by the RTE Entitlements (20.06 per cent) Quality Interventions (17.97 per cent), Gender \& Equity (7.04 per cent) and the lowest for Monitoring of the Scheme (0.09 per cent), Sports \& Physical Education (1.00 per cent) and Vocational Education (1.30 per cent) which are the major areas of concern (Table 2).

\section{Outlays and Releases under SMSA by the Union Government}

This section attempts to examine the pattern of release of funds by the Government of India to State Implementing Societies against the approved budget in selected states of India. In principle, the funds for the programme are approved by the project approval board on the basis of the annual work plan and budget submitted by the individual states. Once approved, funds are released by the union and state governments to single State Implementation Societies (SISs) for implementing the scheme. The current fund sharing pattern under SMSA between the Government of India and the state government is 60 (Centre): 40 (state). For North-Eastern Region and Himalayan states, this fund sharing ratio is $90: 10, \frac{3,10}{1}$

The fund sharing burden clearly shows that the central government has been playing an important role in financing the scheme. However, it is important to have a brief discussion about the distribution of support from the Government of India under Samagra Shiksha Abhiyan.

Table 3 highlights a number of insights, besides looking at the discrepancy between the funds released in approved outlay under Samagra Shiksha Abhiyan. First, on a positive note, in both FY 2018-19 \& FY 2019-20, funds released by the Ministry of Education under Samagra Shiksha Abhiyan has been increasing exponentially across all selected states of India (Andhra Pradesh, Uttar Pradesh, Uttarakhand, West Bengal, Maharashtra, Delhi, Himachal Pradesh and Bihar) except for Maharashtra. Second, although the funds approved by the Ministry of Education under Samgra Shiksha Abhiyan may be as per SMSA norms, but the actual funds released by the Ministry of Education are not in consonance with the financial norms. Third, during the initial years of the programme, the release of funds by particular state has shown a fluctuating nature; for instance, Maharashtra Received Rs. 95051.92 crore in FY 2018-19, whereas it got only Rs. 73423.81 crores in FY 2019-20.11 Sure enough, allocation under SMSA, depends on many factors, such as, economic status, population size, Annual Work Plan and Budgets submitted by states, utilisation capacities, etc. yet the financial pattern across the state seems to be major area of concern (refer column $3 \& 7$ of Table 3 ).

Another important aspect is how this limited Government of India's budgetary approval under Samagra Shiksha Abhiyan has been distributed across states (refer column 4 and 8 of Table 3). In FY 2018-19, on an average, more than 50 per cent of approved outlay is released across the majority of the states (Andhra Pradesh, Maharashtra, Bihar, Himachal Pradesh, Uttarakhand and Uttar Pradesh). In addition to these states, West Bengal released the lower share of approved outlay towards the SMSA, i.e., 29.65 per cent. On the contrary, in FY 2019-20, the highest release of funds was reported in Himachal Pradesh followed by Uttarkhand and Uttar Pradesh. The three states released more than 54 per cent of their approved outlay on Samagra Shiksha Abhiyan. Educationally improving and educationally developed states like Andhra Pradesh, Bihar and Delhi seem to have adopted a uniform and but arbitrary ceiling of 43 per cent of the approved outlay. Further, within states, the lowest release of funds was found in West Bengal followed by Maharashtra with less than 40 per cent of approved outlay. Here, two interesting distinctions happened during the first two initial years of the scheme that, in the year 2019-20, the lowest release of funds was found in the economically developed state of Maharashtra with less than 30 per cent of approved outlay. Another interesting trend that span out is the more than 100 per cent release of funds is found in Delhi, ranging from 354.66 per cent in FY 2018-19 to 43.53 per cent in FY 2019-20.11 This could be on account of the backlog of Sarva Shiksha Abhiyan, Rashtriya Madhyamik Shiksha Abhiyan and Teacher Education being allocated during the initial phase of Samagra Shiksha Abhiyan.

\section{Allocation and Utilisation of Funds under SMSA}

For the present study so as to understand the financial performance of the Samagra Shiksha Abhiyan, this section attempts to examine the resource allocation and 
its expenditure under Samagra Shiksha Abhiyan for the period from 2018-19 to 2019-20. Table 4 gives the absolute figures of the total fund available as well as the expenditure incurred across eight states. ${ }^{4}$ The total fund available includes the funds released by the central and state governments for the recurring and non-recurring component of the scheme and the unspent balance of the previous year together with the interest earned (See Appendix Table A4). Some of the interesting issues of concern emerging from Table 4; firstly, with regard to fund availability, although a rising trend after 2018-19 is visible which marks the beginning of the integrated scheme, concerns regarding the delay in fund flow process persist. Secondly, it is seen that in both FY 2018-19 and 2019-20, the actual expenditure was less than the funds available, which depicts the problem of under-utilisation. Some of the prospective reasons for under-utilisation could be under-allocation, lack of coordination and delay in release of funds.

A closer look at the disaggregated funds availability and expenditure statistics of central and state government funds for education across eight states reveals that the expenditure ranged between 45 per cent in West Bengal and Uttarakhand to more than seventy per cent higher
- 72.60 per cent in Uttar Pradesh during FY 2018-19. On the contrary, in financial year 2019-20, there is a significant decline in the utilisation of funds ranging between 40 per cent in Delhi to 65 per cent in Himachal Pradesh. During both the years, expenditure was much lower than what was available from the central and state government across all eight states. In case of four statesBihar, Delhi, Uttar Pradesh and Maharashtra, it is found that more than 60 per cent of allocated funds are utilised in 2018-19 which came down to less than 55 per cent in 2019-20. The remaining three states namely Himachal Pradesh, Uttarakhand and West Bengal have improved their utilisation during 2019-20 over 2018-19. Thus, the state-wise expenditure patterns point towards the existence of inequities in utilisation of funds throughout the period of study, which depicts that although funds were available, but, were not spent adequately resulting in under achievement of goals/targets.

\section{Conclusions}

In this paper, an attempt is made to unpack the planning and budgetary processes of the newly launched scheme Samagra Shiksha Abhiyan in selected states of India.

Table 3. Funds Released from Government of India against Approved AWP\&B under SMSA in Selected States of India (Rs. in lakhs)

\begin{tabular}{|c|c|c|c|c|c|c|c|c|}
\hline \multirow[b]{2}{*}{ State } & \multicolumn{4}{|c|}{ FY 2018-19 } & \multicolumn{4}{|c|}{ FY 2019-20 } \\
\hline & $\begin{array}{c}\text { Budget } \\
\text { approved }\end{array}$ & $\begin{array}{l}\text { Centre to } \\
\text { allocate } \\
@ 60: 40\end{array}$ & $\begin{array}{l}\text { Central } \\
\text { share } \\
\text { released }^{*}\end{array}$ & $\begin{array}{l}\text { Share of } \\
\text { funds } \\
\text { released } \\
\text { to approved }\end{array}$ & $\begin{array}{c}\text { Budget } \\
\text { approved }\end{array}$ & $\begin{array}{c}\text { Centre } \\
\text { allocation } \\
@ 60: 40\end{array}$ & $\begin{array}{l}\text { Central } \\
\text { share } \\
\text { released }{ }^{\star}\end{array}$ & $\begin{array}{l}\text { Share of } \\
\text { funds } \\
\text { released } \\
\text { to } \\
\text { approved }\end{array}$ \\
\hline & $(1)$ & $(2)$ & (3) & $(4)$ & (5) & (6) & (7) & $(8)$ \\
\hline $\begin{array}{l}\text { Andhra } \\
\text { Pradesh }\end{array}$ & 192717.00 & 115630.2 & 95096.76 & 49.35 & 254874.35 & 152924.61 & 105996.21 & 41.59 \\
\hline Bihar & 719280.47 & 431568.282 & 305837.73 & 42.52 & 732626.54 & 439575.924 & 326693.12 & 44.59 \\
\hline Delhi & 3942.29 & 2365.374 & 13981.74 & 354.66 & 59031.96 & 35419.176 & 25698.06 & 43.53 \\
\hline $\begin{array}{l}\text { Himachal } \\
\text { Pradesh }\end{array}$ & 64472.52 & 38683.512 & 43295.44 & 67.15 & 68876.93 & 41326.158 & 47315.93 & 68.70 \\
\hline Maharashtra & 193121.64 & 115872.984 & 95051.92 & 49.22 & 253138.75 & 151883.25 & 73423.81 & 29.01 \\
\hline Uttar Pradesh & 913200.53 & 547920.318 & 462541.04 & 50.65 & 922907.76 & 553744.656 & 498559.56 & 54.02 \\
\hline Uttarakhand & 83085.66 & 49851.396 & 51138.26 & 61.55 & 75280.96 & 45168.576 & 51187.76 & 68.00 \\
\hline West Bengal & 367381.99 & 220429.194 & 108934.52 & 29.65 & 424849.3 & 254909.58 & 157905.49 & 37.17 \\
\hline
\end{tabular}

Note: ${ }^{\star}$ Central share released as on $24^{\text {th }}$ January, 2020 (Ad-hoc $+1^{\text {st }}+2^{\text {nd }}$ Instalment).

Source: PAB Minutes $(2018,2019)$, MoE data, India Stat and Author's calculations. 
Table 4. Details of Allocation and Fund Utilisation under Samagra Shiksha Abhiyan (Rs. in lakhs)

\begin{tabular}{|l|c|c|c|c|c|c|}
\hline & \multicolumn{3}{|c|}{$\mathbf{2 0 1 8 - 1 9}$} & \multicolumn{2}{c|}{$\mathbf{2 0 1 9 - 2 0}$} \\
\hline State & $\begin{array}{c}\text { Total funds } \\
\text { available }\end{array}$ & Expenditure & $\begin{array}{c}\text { Share of funds } \\
\text { utilised }\end{array}$ & $\begin{array}{c}\text { Total fund } \\
\text { available }\end{array}$ & $\begin{array}{c}\text { Expenditure } \\
\text { Share of funds } \\
\text { utilised }\end{array}$ \\
\hline Andhra Pradesh & 277398 & 190605.61 & 68.71 & 312588 & 179234.81 & 57.34 \\
\hline Bihar & 874828 & 558747.65 & 63.87 & 862507 & 421610 & 48.88 \\
\hline Delhi & 51153 & 35063.19 & 68.55 & 68664 & 27913 & 40.65 \\
\hline $\begin{array}{l}\text { Himachal } \\
\text { Pradesh }\end{array}$ & 81479 & 52079.81 & 63.92 & 84619 & 54890 & 64.87 \\
\hline Maharashtra & 248194 & 146341.28 & 58.96 & 282070 & 138280 & 49.02 \\
\hline Uttar Pradesh & 943078 & 684631.10 & 72.60 & 962862 & 519171 & 53.92 \\
\hline Uttarakhand & 105506 & 47717.44 & 45.23 & 107099 & 51397 & 47.99 \\
\hline West Bengal & 442584 & 199768.38 & 45.14 & 451950 & 279831 & 61.92 \\
\hline
\end{tabular}

Source: PAB Minutes (2018, 2019). Datasets at https://openbudgetsindia.org/dataset/samagra-shiksha-abhiyan-smsa-2018-19-to-2019-20

In doing so, the present study highlights a number of policy and implementation gaps in the programme. The important issues at implementation level are the gap between proposed $v s$. approved outlay by the project approval board, actual amount released by the centre to states and low utilisation levels for Samagra Shiksha Abhiyan. As evident from the state level analysis, for both the years, there is a significant gap between the resources demanded and approved under the scheme. No state has been approved for 100 per cent of the approved outlay for SMSA. But, there is an inclining trend in the total budget approved for scheme across all states except Uttarakhand. Further, the component-wise breakup of total approval for Samagra Shiksha Abhiyan reveals that the scheme focused more on elementary education and, to some extent, secondary education and neglected teacher education across 8 states. However, the other critical interventions like Access \& Retention, Quality Interventions, Vocational Education, Teacher Education, Inclusive Education, Gender \& Equity, Monitoring of the Scheme, Programme Management, RTE Entitlements, Sports \& Physical Education and Salary of Teachers etc. are sparsely approved under Secondary and Teacher Education. Thus, the analysis evidences that the integration has not helped much in improving the scenario of secondary and teacher education in selected states of India.

Given that Samagra Shiksha Abhiyan is the major flagship programme for school education, initiated by the Government of India in partnership with states with fund sharing arrangements, this paper has examined the distribution of support from the union government and highlighted a number of challenges. During the study period, it is observed that resources released by the centre across states are very uneven, but the approved outlay by the Ministry of Education under Samagra Shiksha Abhiyan has been increasing exponentially; this questions the efficiency and requirement of funding with regard to the targets set. Also, with regard to the utilisation of resources, the entire period of study is marked by the under-utilisation of resources.

In light of the above findings, the study suggests the need to opt for a holistic approach in policy design, more emphasis on secondary schooling and adequate provisioning for the scheme along with ensuring the twin principles of equity and efficiency in the education system.

\section{References}

1. Census of India Website: Office of the Registrar General \& Census Commissioner, India. (Year). Retrieved from https://censusindia.gov.in/, accessed on $25^{\text {th }}$ November, 2020.

2. Centre for Budget and Governance Accountability. Budgetary Analysis of Samagra Shiksha Abhiyan: A Case Study of Two Districts in Andhra Pradesh \& Uttar Pradesh. 2020. Retrieved from https://www.cbgaindia. org/wp-content/uploads/2020/09/Budgetary-Analysis-ofSamagra-Shiksha-Abhiyan.pdf

3. Department of School Education and Literacy, Ministry of Education. Samagra Shiksha Abhiyan An Integrated Scheme 
for School Education Framework for Implementation. 2018. Retrieved from https://samagra.education.gov.in/ docs/Framework_IISE\%20_F.pdf

4. India Budget | Ministry of Finance | Government of India. Retrieved from https://www.indiabudget.gov.in/, accessed on $20^{\text {th }}$ January, 2021.

5. Major Initiatives | Government of India, Ministry of Education. Retrieved from https://www.education.gov.in/ en, accessed on $20^{\text {th }}$ February, 2020.

6. Ministry of Education. PAB Minutes. (2018-19 to 2019-20). Retrieved from https://dsel.education.gov.in/pab-minutes

7. Ministry of Statistics and Programme Implementation, Government of India. Key Indicators of Social Consumption in India Education $71^{\text {st }}$ Round. (2014). Retrieved from http://www.mospi.nic.in/sites/default/files/publication_ reports/nss_71st_ki_education_30june15.pdf

8. Ministry of Statistics and Programme Implementation Government of India. Household Social Consumption on
Education in India-NSS $75^{\text {th }}$ Round. (2017). Retrieved from http://mospi.nic.in/sites/default/files/publication_reports/ Report_585_75th_round_Education_final_1507_0.pdf

9. Rashtriya Madhyamik Shiksha Abhiyan (RMSA) | Government of India, Ministry of Education. (2010). Retrieved from https://www.education.gov.in/en/rmsa, accessed on $19^{\text {th }}$ December, 2020.

10. Samagra Shiksha. (2018). Retrieved from https://samagra. education.gov.in/, accessed on $20^{\text {th }}$ October, 2020.

11. Socio-Economic Statistical Data and Facts About India: Indiastat. Retrieved from https://www.indiastat.com/, accessed on $20^{\text {th }}$ April, 2021.

12. THE 17 GOALS | Sustainable Development. (2015). Retrieved from https://sdgs.un.org/goals

13. UDISE + Dashboard. (Year). Retrieved from https:// dashboard.udiseplus.gov.in/\#/home, accessed on $25^{\text {th }}$ November, 2020.

\section{Appendix}

Table A1. States Selected for Analysis

\begin{tabular}{|c|c|c|}
\hline States & Zone & $\begin{array}{c}\text { Literacy rate, } \\
2011(\%)^{1}\end{array}$ \\
\hline Andhra Pradesh & Southern & 67.66 \\
\hline Bihar & Eastern & 63.82 \\
\hline Delhi & Northern & 86.34 \\
\hline Himachal Pradesh & Northern & 83.78 \\
\hline Maharashtra & Western & 82.91 \\
\hline Uttar Pradesh & Central & 69.72 \\
\hline Uttarakhand & Central & 79.63 \\
\hline West Bengal & Eastern & 77.08 \\
\hline
\end{tabular}

Source: Census of India, (2011)1.

Table A2. Meeting of the Project Approval Board of SMSA for the Year 2018-19 and 2019-20

\begin{tabular}{|l|c|c|}
\hline \multicolumn{3}{|c|}{ Project Approval Meeting } \\
\hline States & FY 2018-19 & FY 2019-20 \\
\hline Andhra Pradesh & $9^{\text {th }}$ May & $20^{\text {th }}$ May \\
\hline Bihar & $20^{\text {th }}$ June & $29^{\text {th }}$ May \\
\hline Delhi & $13^{\text {th }}$ June & $6^{\text {th }}$ May \\
\hline Himachal Pradesh & $06^{\text {th }}$ June & $8^{\text {th }}$ May \\
\hline Maharashtra & $10^{\text {th }}$ May & $20^{\text {th }}$ May \\
\hline Uttar Pradesh & $14^{\text {th }}$ June & $13^{\text {th }}$ June \\
\hline Uttarakhand & $7^{\text {th }}$ June & $8^{\text {th }}$ May \\
\hline West Bengal & $21^{\text {st }} J u n e$ & $28^{\text {th }}$ May \\
\hline
\end{tabular}

Source: PAB Minutes $(2018,2019)$. 
Table A3. Categorisation of Components under Samagra Shiksha Abhiyan

\begin{tabular}{|c|c|}
\hline Broad category & Interventions included \\
\hline Access \& Retention & Opening up of new Residential School/Hostels, and Strengthening of Existing Schools \\
\hline \multirow[t]{2}{*}{ RTE Entitlements } & Free Uniforms, Free Textbooks and Special Training of Out of School Children (OoSC) \\
\hline & $\begin{array}{l}\text { Learning Enhancement Programme for students, Assessment at National \& State Level through } \\
\text { NCERT/External Agencies, Composite school grant to all government schools on Annual basis, } \\
\text { Strengthening of school libraries, ICT and Digital Initiatives for class } 6^{\text {th }} \text { to } 12^{\text {th }} \text {, Career Guidance } \\
\text { and Counselling sessions, Funds for innovation, Support at Pre-school for training of Anganwadi } \\
\text { workers, Rastriya Avishkar Abhiyan and Academic support through Block Resource Centre } \\
\text { (BRC)/Cluster Resource Centre (CRC)/Urban Resource Centre (URC). }\end{array}$ \\
\hline Quality Interventions & $\begin{array}{l}\text { Funds for Quality (LEP, Innovation, Guidance etc), Assessment at National \& State Level, } \\
\text { Training for In-service Teacher and Head Teachers, Composite School Grant, strengthening of } \\
\text { school libraries, Rastriya Aavishkar Abhiyan, ICT and Digital Initiatives, Support at Pre- Primary } \\
\text { Level and Academic support through Block Resource Centre (BRC)/Cluster Resource Centre } \\
\text { (CRC)/Urban Resource Centre (URC). }\end{array}$ \\
\hline Teacher Education & $\begin{array}{l}\text { Strengthening of physical infrastructure\& Establishment of new District Institutes of Education } \\
\text { and Training, Faculty Development Programme for Teacher Educator, Annual Grant and } \\
\text { Technology support for Teacher Education Institutions (TEIs),National Teacher Portal -Diksha } \\
\text { and Academic support through Block Resource Centre (BRC)/Cluster Resource Centre (CRC) }\end{array}$ \\
\hline Salary of Teachers & Salary of Teachers and Head Masters as per the norms. \\
\hline Gender \& Equity & $\begin{array}{l}\text { Kasturba Gandhi Balika Vidyalaya (KGBVs), Special Projects for Equity like Kishori Manch and } \\
\text { Self defence training for Girls. }\end{array}$ \\
\hline Inclusive Education & Provision for Children with Special Need. \\
\hline Vocational Education & Introduction of Vocational Education at Secondary and higher Secondary \\
\hline Sports \& Physical Education & Flexible funds for sports equipment \\
\hline Monitoring of Scheme & Management Information System- UDISE, Shaala Kosh and Shagun etc. \\
\hline Programme Management & Management, Monitoring, Evaluation and Research (MMER) \\
\hline
\end{tabular}

Source: Compiled from Samagra Shiksha Abhiyan Website \& PAB Minutes $(2018,2019)$.

Table A4. Opening Balance/Spill Over of SMSA for the Year 2018-19 and 2019-20

\begin{tabular}{|l|c|c|}
\hline \multicolumn{2}{|c|}{ Opening Balance } \\
\hline States & FY 2018-19 & FY 2019-20 \\
\hline Andhra Pradesh & 846.81 & 1298.81 \\
\hline Bihar & 1555.47 & 96.32 \\
\hline Delhi & 117.82 & 157.42 \\
\hline Himachal Pradesh & 170.09 & 289.31 \\
\hline Maharashtra & 550.73 & 399.54 \\
\hline Uttar Pradesh & 298.78 & 318.18 \\
\hline Uttarakhand & 224.2 & 271.01 \\
\hline West Bengal & 752.02 & \\
\hline
\end{tabular}

Source: PAB Minutes (2018, 2019). 